\title{
Epidermal Growth Factor (EGF)-Like Transforming Growth Factor (TGF) Activity and EGF Receptors in Ovine Fetal Tissues: Possible Role for TGF in Ovine Fetal Development
}

\author{
MICHAEL FREEMARK AND MARTY COMER \\ Department of Pediatrics, Duke University Medical Center, Durham, North Carolina 27710
}

\begin{abstract}
To determine whether epidermal growth factor (EGF) or EGF-like transforming growth factors (TGFs) are present in ovine fetal tissues, we have tested acid-ethanol extracts of ovine fetal kidney for the ability to induce anchorage-independent growth of normal rat kidney fibroblasts in soft agar and to compete with ${ }^{125} \mathrm{I}$ mouse EGF for binding to receptors in sheep liver. The fetal kidney extract $(20-1000 \mu \mathrm{g}$ protein/ml $)$ stimulated a dose-dependent increase in the number of soft agar colonies of normal rat kidney cells. Approximately $70 \%$ of these colonies measured $\geq 3100 \mu \mathrm{M}^{2}$. The fetal kidney extract was dissolved in $1 \mathrm{M}$ acetic acid and chromatographed on Bio-Gel P 10. Two peaks of TGF-like activity, with approximate MW 14.5K (peak 1) and 9K (peak 2), eluted from the column. Half-maximal effects of pooled peaks 1 and 2 on colony formation were achieved using 100 and 20 $\mu \mathrm{g}$ protein/ml, respectively. Peaks 1 and 2 also competed with ${ }^{125}$ I-mouse EGF for binding to EGF receptors in ovine fetal liver but had no activity in a homologous mouse EGF radioimmunoassay sensitive to 15 pg mouse EGF. Neither TGF activity nor EGF receptor binding activity was detected in Bio-Gel fractions co-eluting with ${ }^{125}$ I-mouse EGF. Specific ${ }^{125}$ I-EGF binding sites in fetal liver were detected as early as midgestation, and the number of EGF binding sites increased markedly in late gestation, exceeding the number of EGF binding sites in the livers of pregnant ewes. These findings demonstrate the presence of TGF-like activity in ovine fetal kidney and high affinity EGF receptors in ovine fetal liver. The absence of EGF receptor activity in Bio-Gel fractions coeluting with ${ }^{125}$ I-mouse EGF suggests that TGF may predominate in the ovine fetus and may play an EGF-like role in ovine fetal development. (Pediatr Res 22: 609-615, 1987)
\end{abstract}

\section{Abbreviations}

EGF, epidermal growth factor TGF, transforming growth factor BSA, bovine serum albumin RIA, radioimmunoassay PBS, phosphate-buffered saline NRK, normal rat kidney

EGF is a single chain polypeptide hormone that was first isolated from mouse submandibular glands. Studies in postnatal

Received July 22, 1986; accepted July 9, 1987.

Correspondence and reprint requests Michael Freemark, M.D., Duke University Medical Center, Box 3080, Durham, NC 27710.

Supported by NIH Grants HD00656 and HD07447 and a Basil O'Connor Starter Grant 5-503 from the March of Dimes. animals implicate a role for EGF in the control of cellular and tissue growth, the regulation of gastric acid secretion, and the modulation of the synthesis and secretion of a number of hormones and peptide growth factors (1). The role of EGF in the fetus, however, is poorly understood. EGF binds to specific receptors in fetal mouse $(2,3)$ and rat $(4)$ tissues and stimulates glycogen synthesis (4) and somatomedin production in fetal rat hepatocytes (5) and human fetal fibroblasts (6). In addition, EGF has mitogenic effects in fetal rat chondrocytes (7) and human fetal adrenal cells (8) and stimulates phospholipid synthesis in fetal rat lung explants (9). However, the concentration of immunoreactive EGF in newborn mouse urine (10), kidney (10), and submaxillary gland (11) and in human cord blood (12) and human newborn urine (13) is low and increases markedly during postnatal life (10-13). These findings suggest that EGF may exert its major role on growth and development after birth. Recent studies have demonstrated that extracts of normal mouse (1416) and rat embryos (17) contain EGF-like TGFs which bind to EGF receptors and share many biologic actions with EGF itself (18-24). These observations suggest a possible role for TGF or a related growth factor as a "fetal EGF."

The demonstration that EGF promotes the growth and maturation of the liver, lung, and epidermal tissues of the fetal lamb in vivo $(25,26)$ suggests a role for EGF or the EGF-like TGFs in ovine fetal development. However, the presence of endogenous EGF or TGF in the ovine fetus has not been established. To determine if EGF or EGF-like TGFs are present in ovine fetal tissues, we have tested acid-ethanol extracts of ovine fetal kidney for the ability to induce anchorage-independent growth of normal rat kidney fibroblasts in soft agar and to compete with radiolabeled EGF for binding to receptors in fetal and postnatal sheep liver.

\section{MATERIALS AND METHODS}

Materials. Purified mouse EGF (lot 85-1342, receptor grade, 98-99\% pure) and rabbit EGF antiserum (lot 85-1126) were purchased from Collaborative Research, Waltham, MA. The preparation of EGF migrated as a single band on polyacrylamide gel electrophoresis. Purified insulin-like growth factor I was kindly provided by Dr. Judson Van Wyk (University of North Carolina at Chapel Hill) and purified rat insulin-like growth factor II (multiplication stimulating activity III-2) was provided by Dr. S. Peter Nissley (N.I.H.). Crystalline porcine insulin was obtained from Eli Lilly (Indianapolis, IN). Ovine placental lactogen (lot 3-23) was prepared as previously described (27) and ovine growth hormone (NIH-GH-S12) was obtained from the National Hormone and Pituitary Program, NIADDK. Normal rat kidney fibroblasts (Clone 49F) were purchased from the American Type Culture Collection, Rockville, MD. 
Detection of TGF-like activity. Aliquots of ovine fetal kidney (days 123-137 of gestation, $n=3$ ) were extracted by a modification of the method of Roberts et al. (28). Fetal kidneys were homogenized at $0^{\circ} \mathrm{C}$ in a solution $(4 \mathrm{ml} / \mathrm{g}$ wet weight) containing $375 \mathrm{ml}$ of $95 \%$ ethanol, $7.5 \mathrm{ml}$ concentrated $\mathrm{HCl}, 33 \mathrm{mg}$ of phenylmethylsulfonyl fluoride, and $20 \mu \mathrm{g} / \mathrm{ml}$ soybean trypsin inhibitor. The volume was adjusted to $6 \mathrm{ml} / \mathrm{g}$ with cold distilled water and the tissue was extracted overnight at $4^{\circ} \mathrm{C}$. The suspension was centrifuged at $10,000 \times g$ for $20 \mathrm{~min}$ at $4^{\circ} \mathrm{C}$. The pellet was re-extracted for $2 \mathrm{~h}$ with a solution containing $375 \mathrm{ml}$ of $95 \%$ ethanol, $105 \mathrm{ml}$ distilled water, and $7.5 \mathrm{ml}$ concentrated $\mathrm{HCl}(2 \mathrm{ml} / \mathrm{g}$ original weight). Supernatants from both extractions were pooled and adjusted to $\mathrm{pH} 5.2$ with concentrated $\mathrm{NH}_{4} \mathrm{OH}$, and $1 \mathrm{ml}$ of $2 \mathrm{M}$ ammonium acetate, $\mathrm{pH} 5.2$ was added per 100 $\mathrm{ml}$ of supernatant. The suspension was centrifuged at $10,000 \times$ $g$ for $20 \mathrm{~min}$ at $4^{\circ} \mathrm{C}$. The supernatant was precipitated at $-20^{\circ}$ $\mathrm{C}$ for $24 \mathrm{~h}$ with 4 volumes of cold ethanol and 2 volumes of cold anhydrous ether. The precipitate was collected by centrifugation at $10,000 \times g$ for $20 \mathrm{~min}$ at $4^{\circ} \mathrm{C}$, redissolved in $1 \mathrm{M}$ acetic acid, dialyzed against $0.2 \mathrm{M}$ acetic acid using Spectropor no. 6 dialysis tubing (MW cutoff 1000, Spectrum Medical, Los Angeles, CA), and lyophilized. The yield of protein was $3.3-4.2 \mathrm{mg} / \mathrm{g}$ wet weight.

The acid-ethanol extract was dissolved in $1 \mathrm{M}$ acetic acid and applied to a Bio-Gel P10 column $(2 \times 46 \mathrm{~cm})$ previously equilibrated in $1 \mathrm{M}$ acetic acid. Fractions $(2.4 \mathrm{ml})$ eluting from the column were lyophilized and assayed for colony-forming activity. Active fractions were pooled and the effects of these pooled fractions were compared to the effect of the crude acid-ethanol extract itself.

Assays of colony-forming activity in soft agar were performed in Dulbecco's modified Eagle's medium containing $10 \%$ calf serum (supplemented medium) as described by Todaro et al. (18). One $\mathrm{ml}$ of supplemented medium containing $0.3 \%(\mathrm{w} / \mathrm{v})$ agar (Difco, BioRad Richmond, CA), $8 \times 10^{3}$ normal rat kidney fibroblasts, and varying amounts of fetal kidney extract or pooled Bio-Gel fractions were pipetted onto a base layer of medium containing $0.5 \%$ agar in $22.6-\mathrm{mm}$ diameter plastic culture dishes (CoStar Data Packaging Corp., Cambridge, MA). The cells were incubated at $37^{\circ} \mathrm{C}$ in a humidified $5 \% \mathrm{CO}_{2} / 95 \%$ air atmosphere, and plates were overlaid with supplemented medium on day 7 . The assay was read unfixed and unstained on day 10 . The total number of colonies (more than six cells) (16) in eight microscopic fields, as well as the number of colonies measuring more than $63 \mu \mathrm{M}$ in diameter $\left(>3100 \mu \mathrm{M}^{2}\right)$ and $94 \mu \mathrm{M}$ in diameter $(>7000$ $\mu \mathrm{M}^{2}$ ), were counted.

Receptor assays. ${ }^{125} \mathrm{I}-\mathrm{EGF}$ was prepared using 1,3,4,6tetrachloro3,6,-diphenyl-glycouril (Iodo-Gen, Pierce Chemical Co., Rockford, IL) as the catalyst. Forty $\mu$ l of a solution containing $3.5 \mu \mathrm{g}$ of EGF and $45 \mu \mathrm{l}$ of $0.3 \mathrm{M}$ phosphate buffer were added to a $12 \times 75$ tube coated with $1 \mu \mathrm{g}$ Iodo-Gen. The iodination reaction was initiated by the addition of $4 \mu \mathrm{l}$ (400 $\mu \mathrm{Ci}$ ) of ${ }^{125}$ Iodine (Amersham Corp., Arlington Heights, IL). The mixture was gently shaken every $30 \mathrm{~s}$ for $4 \mathrm{~min}$ and the reaction was terminated by the addition of $1.0 \mathrm{ml}$ of cold phosphate buffer. ${ }^{125} \mathrm{I}$-EGF was purified by gel filtration on a Sephadex G25 fine column $(30 \times 1.5 \mathrm{~cm})$ eluted with $0.01 \mathrm{M}$ phosphate $\mathrm{pH}$ 7.6 in normal saline containing $10 \mathrm{mM}$ EDTA and $0.1 \%$ bovine serum albumin. The percentage of radioactivity incorporated into ${ }^{125}$ I-EGF was $45-60 \%$, and the specific activity of the iodinated hormone, calculated from the elution profiles of the radiolabeled hormone and free ${ }^{125}$ I on Sephadex G-25, was 55$70 \mu \mathrm{Ci} / \mu \mathrm{g}$ protein. This preparation of radiolabeled EGF migrated as a single band on polyacrylamide gel electrophoresis. The purity of the radiolabeled EGF was confirmed by autoradiography of the dried gels using purified mouse EGF as a standard.

Particulate microsomal fractions of ovine fetal liver were prepared by differential centrifugation as described by Tsushima and Friesen (29). Groups of three or four pregnant Dorset ewes at 70-79, 94-98, 118-123, and 130-141 days of gestation (term
$=145$ days), groups of three neonatal male lambs at 1,3 , and 7-9 days of age, and four sheep at 37 days to 7 months of age were killed rapidly by the intrathecal administration of Letalis (sodium pentobarbital, Barber Veterinary Supply Co., Richmond, VA). Livers of fetal, pregnant, and postnatal nonpregnant sheep were rapidly removed and immediately frozen at $-70^{\circ} \mathrm{C}$. Frozen liver samples were subsequently thawed and homogenized in ice-cold $0.3 \mathrm{M}$ sucrose containing $2 \mathrm{mM}$ EDTA, pH 7.4. The homogenate was filtered through cheesecloth and centrifuged at $1500 \times g$ for $30 \mathrm{~min}$. The supernatant was recovered and centrifuged at $11,000 \times g$ for $30 \mathrm{~min}$. The resulting supernatant was then recentrifuged at $100,000 \times g$ for $60 \mathrm{~min}$ and the pellet was resuspended in $25 \mathrm{mM}$ Tris- $\mathrm{HCl}, \mathrm{pH} \mathrm{7.6}$, containing $10 \mathrm{mM} \mathrm{MgCl}_{2}$ and $0.1 \% \mathrm{BSA}, \mathrm{pH} 7.6$ (assay buffer). The protein contents of the membrane suspensions were determined by the method of Bradford (30).

The percentage of homogenate protein remaining in the $100,000 \times g$ membrane fractions and the membrane activity of 5 'nucleotidase (31) were examined in livers of fetal lambs at 96 and 137 days of gestation and postnatal sheep at 7 months of age. The percentage of homogenate protein remaining in the hepatic microsomal fractions averaged $6.84 \pm 0.91 \%$ (mean \pm $\mathrm{SE}, n=9$ ) and did not differ significantly among the three groups. The 5 'nucleotidase activities in hepatic microsomes from fetal lambs at 96 and 137 days of gestation were $5.86 \pm 0.71$ (mean $\pm \mathrm{SE}, n=3$ ), $6.84 \pm 0.88$ (mean $\pm \mathrm{SE}, n=3$ ) $\mu$ mol phosphorus/mg/h, respectively, while the 5 'nucleotidase activity in hepatic microsomes from postnatal sheep at 7 months of age was $4.99 \pm 1.02$ (mean $\pm \mathrm{SE}, n=3) \mu$ mol phosphorus $/ \mathrm{mg} / \mathrm{h}$.

${ }^{125}$ I-EGF $(50,000 \mathrm{cpm}$, approximately $2-3 \mathrm{ng})$ was incubated with membrane protein and unlabeled hormone in assay buffer (total volume $0.5 \mathrm{ml}$ ) for $30 \mathrm{~min}$ to $24 \mathrm{hr}$ at 4,23 , and $37^{\circ} \mathrm{C}$. Incubations were terminated by the addition of $2 \mathrm{ml}$ of ice-cold assay buffer to each assay tube and the tubes were centrifuged at $3000 \times g$ for $30 \mathrm{~min}$. After the pellets were washed twice with ice-cold assay buffer, the radioactivity in each pellet was determined by $\gamma$ scintillation spectrometry.

The total binding of ${ }^{125} \mathrm{I}$-EGF was expressed as the percent of iodinated hormone bound to hepatic membranes. Specific binding was calculated by subtracting the amount of binding which occurred in the presence of excess $(500 \mathrm{ng})$ unlabeled hormone (nonspecific binding) from the total binding. Specific binding of ${ }^{125}$ I-EGF at all stages of development increased linearly with increasing concentrations of membrane protein, reaching maximum binding with $0.5-1.25 \mathrm{mg}$ of protein per assay tube. Maximal specific binding occurred at $2 \mathrm{~h}$ of incubation at room temperature or at $24 \mathrm{~h}$ of incubation at $4^{\circ} \mathrm{C}$.

Dose-response curves for the binding of ${ }^{125} \mathrm{I}$-EGF were analyzed by the method of Scatchard (32), and Scatchard plots were utilized to determine the affinity and number of hormone binding sites.

The reversibility of ${ }^{125} \mathrm{I}$-EGF binding to hepatic membranes was assessed by incubating approximately 75,000 cpm (approximately $3-4.5 \mathrm{ng}$ ) of ${ }^{125} \mathrm{I}-\mathrm{EGF}$ with $1 \mathrm{mg}$ membrane protein for $20 \mathrm{~h}$ at $4^{\circ} \mathrm{C}$. At the end of the incubation period, the reaction mixture was diluted with $2 \mathrm{ml}$ of assay buffer containing $500 \mathrm{ng}$ of unlabeled EGF. The specific binding of ${ }^{125} \mathrm{I}$-EGF to hepatic membranes remaining after a subsequent 4 -h incubation at room temperature was compared to the specific binding of ${ }^{125} \mathrm{I}-\mathrm{EGF}$ at the end of the initial 20 -h incubation period. The binding of ${ }^{125} \mathrm{I}-$ EGF was reversible within $2 \mathrm{~h}$ following the addition of a 100 fold excess of unlabeled hormone.

To determine the extent of degradation of the radiolabeled EGF during incubation with hepatic microsomes, approximately $75,000 \mathrm{cpm}$ of ${ }^{125} \mathrm{I}$-EGF was incubated with $500 \mu \mathrm{g}$ hepatic membrane protein (postnatal sheep age 7 months) in the absence of unlabeled EGF for $20 \mathrm{~h}$ at $4^{\circ} \mathrm{C}$. The reaction was terminated by the addition of cold assay buffer followed by centrifugation at $3000 \times g$. An aliquot of the supernatant containing ${ }^{125}$ I-EGF was then incubated with fresh hepatic membranes in the presence 
or absence of excess unlabeled EGF at $4^{\circ} \mathrm{C}$ for an additional 20 $h$. The specific binding was compared to the binding of an aliquot of ${ }^{125}$ I-EGF which had not been previously incubated with membranes. These studies indicated that less than $5 \%$ of the tracer was degraded during a 20 -h incubation at $4^{\circ} \mathrm{C}$.

Detection of $E G F$-like receptor activity. Aliquots $(400 \mu \mathrm{l})$ of acid-ethanol extract fractions eluting from Bio-Gel were lyophilized and dissolved in $25 \mathrm{mM}$ Tris, $10 \mathrm{mM} \mathrm{MgCl}_{2}$, and $0.1 \%$ BSA (receptor assay buffer). The effects of these lyophilized BioGel fractions on the binding of ${ }^{125}$ I-EGF $(75,000 \mathrm{cpm}$, approximately $3-4.5 \mathrm{ng}$ ) to sheep liver microsomes (500 $\mu \mathrm{g}$ membrane protein) at $4^{\circ} \mathrm{C}$ for $20 \mathrm{~h}$ were compared to the effects of varying amounts $(0.5-250 \mathrm{ng})$ of unlabeled mouse EGF.

To be certain that apparent receptor-binding activity detected in Bio-Gel fractions did not result from degradation of the EGF tracer, we preincubated 1.5 million cpm of ${ }^{125} \mathrm{I}-\mathrm{EGF}$ with lyophilized Bio-Gel fractions (1 mg protein) for $20 \mathrm{~h}$ at $4^{\circ} \mathrm{C}$. An aliquot of this reaction mixture containing $30,000 \mathrm{cpm}$ of ${ }^{125} \mathrm{I}$ EGF (approximately $2 \mathrm{ng}$ ) was then incubated with $500 \mu \mathrm{g}$ of sheep hepatic membrane protein in the presence or absence of $250 \mathrm{ng}$ of unlabeled EGF for $20 \mathrm{~h}$ at $4^{\circ} \mathrm{C}$. This incubation also contained $0.02 \mathrm{mg}$ of Bio-Gel protein, but this represented less than $0.15 \mathrm{ng}$ equivalents of EGF-receptor binding activity and thus had negligible effect on the binding of ${ }^{125}$ I-EGF to sheep liver microsomes. An additional 1.5 million cpm of ${ }^{125}$ I-EGF was preincubated with receptor assay buffer alone. An aliquot of this second reaction mixture containing $30,000 \mathrm{cpm}$ of ${ }^{125}$ I-EGF was then incubated with $500 \mu \mathrm{g}$ of sheep hepatic membrane protein in the presence or absence of unlabeled EGF. The specific binding of the EGF tracer which had been preincubated with lyophilized Bio-Gel protein was compared to the specific binding of the EGF tracer which had been preincubated with assay buffer alone.

To be certain that apparent receptor-binding activity identified in Bio-Gel fractions did not result from proteolysis of hepatic EGF receptors, we preincubated hepatic microsomes $(1 \mathrm{mg}$ of protein) from 1-day-old postnatal sheep with lyophilized Bio-Gel fractions $\left(0.5 \mathrm{mg}\right.$ protein) for $20 \mathrm{~h}$ at $4^{\circ} \mathrm{C}$. An additional $1 \mathrm{mg}$ of hepatic microsomal protein was preincubated with receptor assay buffer alone. Following the preincubation period, the hepatic microsomes were washed with ice-cold assay buffer and resuspended in a total volume of $500 \mu \mathrm{l}$. An equal volume of $0.15 \mathrm{M} \mathrm{NaCl} / 0.05 \mathrm{M}$ glycine, $\mathrm{pH} 2.5$ was added to each tube. In a separate experiment, we demonstrated that treatment of hepatic microsomes with $0.15 \mathrm{M} \mathrm{NaCl} / 0.05 \mathrm{M}$ glycine, $\mathrm{pH} 2.5$ for $1 \mathrm{~min}$ at room temperature caused the dissociation of 90 $95 \%$ of ${ }^{125}$ I-EGF previously bound but did not affect the subsequent binding of ${ }^{125} \mathrm{I}-\mathrm{EGF}$. Thus, treatment of hepatic microsomes with acidified glycine would be expected to dissociate any extract-containing EGF or TGF-like material bound during the preincubation period. After $1 \mathrm{~min}$ of incubation with the acidified glycine solution, the microsomes were washed again with ice-cold assay buffer, resuspended, and then incubated with ${ }^{125} \mathrm{I}$ $\operatorname{EGF}(75,000 \mathrm{cpm})$ in the presence or absence of $250 \mathrm{ng}$ unlabeled EGF. The specific binding of ${ }^{125} \mathrm{I}-\mathrm{EGF}$ to hepatic microsomes preincubated with lyophilized Bio-Gel protein was compared to the specific binding of ${ }^{125}$ I-EGF to hepatic microsomes preincubated with assay buffer alone.

Detection of EGF-like immunoactivity. Fractions eluting from Bio-Gel were also assayed for immunoactivity in a homologous mouse EGF RIA performed by a modification of the method of Hoath et al. (33). Unlabeled EGF standard or aliquots of pooled Bio-Gel peaks 1 or 2 were dissolved in PBS pH 7.4 and were incubated with $100 \mu \mathrm{l}$ antimouse EGF antibody (final concentration $1: 250,000$ ) in assay buffer (PBS pH 7.4 containing $1 \%$ bovine serum albumin and $4 \mu \mathrm{l}$ normal rabbit serum per tube) for $24 \mathrm{~h}$ at $4^{\circ} \mathrm{C} .{ }^{125} \mathrm{I}$-EGF $(20,000 \mathrm{cpm})$ was then added to each tube. The total volume of each tube was $0.5 \mathrm{ml}$. After an additional incubation for $24 \mathrm{~h}$ at $4^{\circ} \mathrm{C}$, the samples were incubated for $30 \mathrm{~min}$ at room temperature with $25 \mu \mathrm{l}$ goat antirabbit immunoglobulin $C$ serum. Five hundred $\mu \mathrm{l}$ of $6 \%$ polyethylene glycol 8000 (J.T. Baker Chemical Co., Phillipsburg, NJ) were then added to each tube. The tubes were centrifuged at $3000 \times$ $g$ for $30 \mathrm{~min}$, and the radioactivity in the pellets was counted by $\gamma$ scintillation spectrometry. Results were calculated after loglogit transformation.

\section{RESULTS}

To determine whether ovine fetal kidney contains TGF-like activity, acid-ethanol extracts of fetal kidney were tested for the ability to induce the formation of colonies of NRK fibroblasts in soft agar. As shown in Figure 1, the fetal kidney extract (20$1000 \mu \mathrm{g}$ protein $/ \mathrm{ml}$ ) stimulated a dose-dependent increase in the number of soft agar colonies ( $>6$ cells). Concentrations of extract less than $20 \mu \mathrm{g} / \mathrm{ml}$ were without effect. Approximately $70 \%$ of the soft agar colonies measured more than $3100 \mu \mathrm{M}^{2}$. When NRK cells were exposed to the highest concentrations of extract protein, approximately $25 \%$ of the colonies measured more than $7000 \mu \mathrm{M}^{2}$. In contrast, NRK cells exposed to media alone formed no colonies measuring more than $100 \mu \mathrm{M}^{2}$.

The acid-ethanol extract ( $30 \mathrm{mg}$ protein) was dissolved in $1 \mathrm{M}$ acetic acid and chromatographed on Bio-Gel P10. Fractions eluting from the column were lyophilized and then assayed for colony-forming activity. As shown in Figure 2, two peaks of TGF-like activity, with approximate MW $14.5 \mathrm{~K}$ (peak 1) and 9 $\mathrm{K}$ (peak 2), eluted from the column. No TGF-like activity was detected in column fractions coeluting with ${ }^{125} \mathrm{I}$-mouse EGF. The protein concentrations of pooled peaks 1 (corresponding to BioGel fractions 16-22) and 2 (corresponding to fractions 28-32) which produced half-maximal stimulation of colony formation were 100 and $20 \mu \mathrm{g}$ protein/ml, respectively (Fig. 1).

Fractions eluting from the Bio-Gel column were also assayed for activity in competing with radiolabeled mouse EGF for binding to EGF receptors. For this purpose, we developed an EGF radioreceptor assay using radiolabeled mouse EGF and hepatic microsomes from fetal lambs and postnatal nonpregnant and pregnant sheep. The binding of ${ }^{125}$ I-EGF to sheep liver was

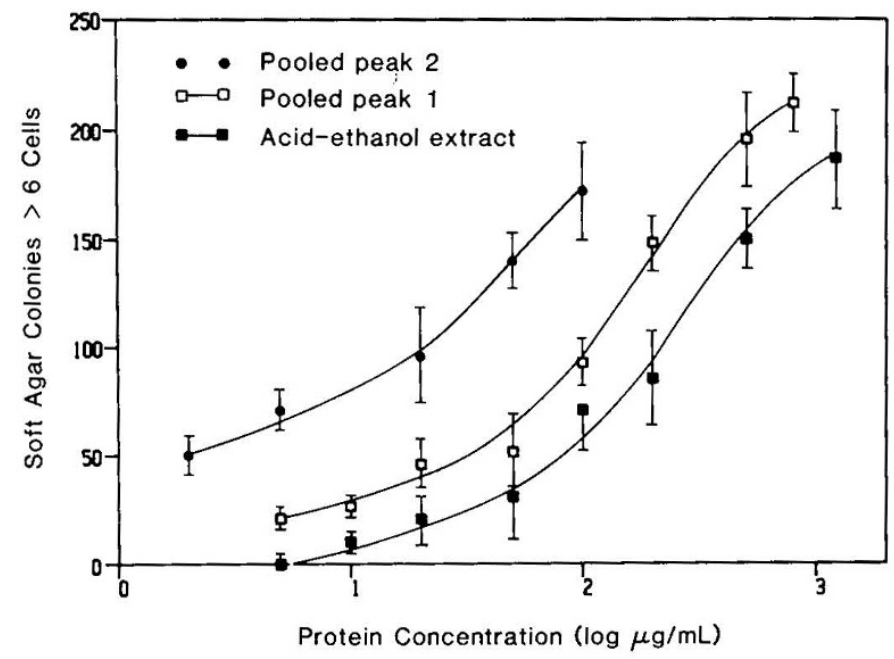

Fig. 1. TGF-like activity in ovine fetal kidney. NRK fibroblasts $(8 \times$ $10^{3}$ cells) were incubated in media containing agar and varying concentrations of a crude acid-ethanol extract of fetal kidney ( - ) or of pooled lyophilized fractions (peak $1 \square-\square$ corresponding to fractions $16-22$ and peak $2 \multimap$ corresponding to fractions 28-32) eluting during chromatography of the acid-ethanol extract on Bio-Gel P10 (see legend to Fig. 2). The total number of soft agar colonies (more than six cells) in eight microscopic fields were counted. Values represent the mean \pm SE of three determinations using the kidneys of a fetal lamb at 137 days of gestation. Similar results were obtained using kidneys from fetal lambs at 131 and 133 days of gestation. 


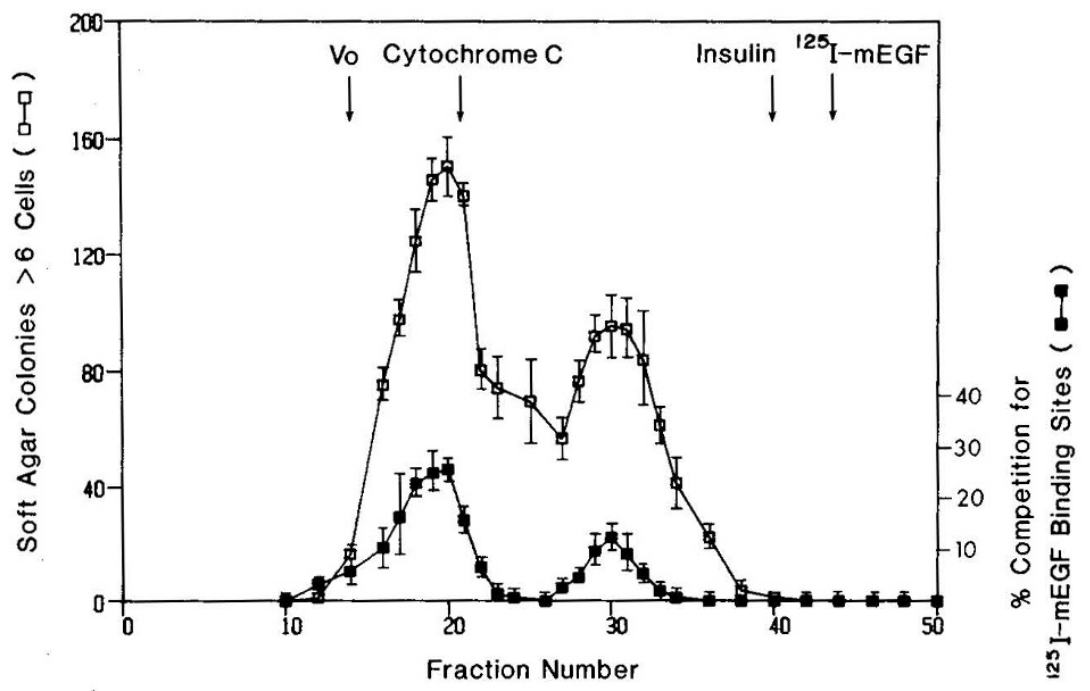

Fig. 2. Chromatography of an acid-ethanol extract of fetal kidney on Bio-Gel P10. Thirty mg of crude acid-ethanol extract protein prepared from the kidneys of a fetal lamb at 137 days of gestation were dissolved in $1 \mathrm{M}$ acetic acid and applied to a Bio-Gel P10 column ( $2 \times 46 \mathrm{~cm})$. The column was equilibrated and eluted with $1 \mathrm{M}$ acetic acid and $2.4 \mathrm{ml}$ fractions were collected. Aliquots $(400 \mu \mathrm{l})$ of these fractions were lyophilized and tested for the ability to stimulate colonly formation of NRK cells in soft agar and to compete with ${ }^{125}$ I-mEGF for binding to EGF receptors in sheep liver. The total number of soft agar colonies ( $\square-\square$, more than six cells) in eight microscopic fields was counted. Each point represents the mean \pm SE of three determinations. Hepatic microsomes $\left(500 \mu \mathrm{g}\right.$ membrane protein) from a newborn lamb were incubated with ${ }^{125} \mathrm{I}-\mathrm{mEGF}(0.5$ $\mathrm{nM})$ in the absence or presence of varying amounts of unlabeled mEGF $(0.25-250 \mathrm{ng})$ or of the lyophilized Bio-Gel aliquots for $20 \mathrm{~h}$ at $4^{\circ} \mathrm{C}$. The specific binding of ${ }^{125} \mathrm{I}$-mEGF under these conditions was $13.4 \pm 1.4 \%$ per $\mathrm{mg}$ protein. Half-maximal inhibition of ${ }^{125} \mathrm{I}$-mEGF binding was achieved using $1.9 \mathrm{ng}$ unlabeled mEGF per ml. Values for percent competition of EGF binding caused by Bio-Gel fractions ( $\square)$ represent the mean \pm $\mathrm{SE}$ of three determinations. The molecular weight markers included dextran blue (Vo), cytochrome C (13K), insulin (6K), and ${ }^{125} \mathrm{I}-\mathrm{mEGF}$. Similar results were obtained using acid-ethanol extracts of kidneys of fetal lambs at 133 and 137 days of gestation.

specific, saturable, reversible, and time and temperature dependent. Unlabeled mouse EGF caused a dose-dependent inhibition of the binding of ${ }^{125} \mathrm{I}-\mathrm{EGF}$, with half-maximal displacement of radiolabeled EGF by $1.7 \mathrm{ng} / \mathrm{ml}(0.3 \mathrm{nM})$ unlabeled EGF (Fig. 3). In contrast, insulin-like growth factors I and II, insulin, ovine growth hormone, and ovine placental lactogen were without effect.

The binding of ${ }^{125} \mathrm{I}$-EGF to sheep liver microsomes was inhibited by lyophilized fractions eluting from the Bio-Gel column. As shown in Figure 2, two peaks of EGF-like receptor-binding activity, with approximate MW 14.5 and $9 \mathrm{~K}$, were detected. The two peaks of receptor binding activity coeluted with the two peaks of TGF-like activity, but neither TGF-like activity nor EGF receptor binding activity coeluted with ${ }^{125} \mathrm{I}$-mouse EGF.

To be certain that the apparent receptor-binding activity identified in Bio-Gel fractions did not result from degradation of the EGF tracer, we compared the specific binding of EGF tracer which had been preincubated with active Bio-Gel fractions with that of EGF tracer preincubated with assay buffer alone. The specific binding of the EGF tracer previously exposed to aliquots of Bio-Gel pooled peak 1 (14.5 $\pm 2.3 \%$ per mg protein) was similar to that of EGF tracer preincubated with assay buffer alone $(15.3 \pm 2.1 \%$ per mg protein).

To be sure that the active Bio-Gel fractions did not inhibit the binding of ${ }^{125} \mathrm{I}-\mathrm{EGF}$ by causing proteolysis of hepatic EGF receptors, we examined the binding of radiolabeled EGF to hepatic microsomes preincubated with active Bio-Gel fractions and to microsomes preincubated with receptor assay buffer alone. The specific binding of ${ }^{125}$ I-EGF to hepatic microsomes preincubated with Bio-Gel pooled peak $1(21.4 \pm 1.5 \%$ per mg protein, $n=3)$ was similar to the specific binding of ${ }^{125}$ I-EGF to hepatic microsomes preincubated with assay buffer alone $(20.8 \pm 2.1 \%$ per $\mathrm{mg}$ protein, $n=3$ ).

When $30 \mathrm{mg}$ of acid-ethanol extract protein was applied to the Bio-Gel column, a total of $9.8 \mathrm{ng}$ equivalents of EGF receptor binding activity was recovered in the active column fractions.

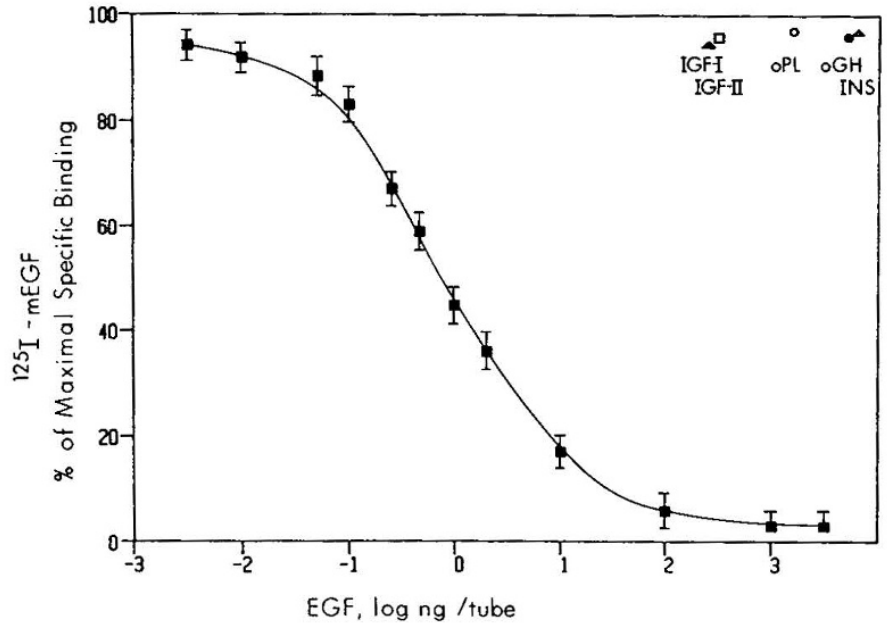

Fig. 3. Inhibition of the binding of ${ }^{125} \mathrm{I}$-EGF to hepatic membranes of fetal lambs (138 days of gestation) by unlabeled mouse EGF $(\square)$, insulin-like growth factors I $(\boldsymbol{\Lambda})$ and II $(\square)$, insulin $(\triangle)$, ovine placental lactogen $(O)$, and ovine growth hormone $(\bullet) .{ }^{125}$ I-EGF $(0.5$ $\mathrm{nM}$ ) was incubated with $0.5 \mathrm{mg}$ of membrane protein in a total volume of $0.5 \mathrm{ml}$ for $20 \mathrm{~h}$ at $4^{\circ} \mathrm{C}$. The number of ${ }^{125} \mathrm{I}$-EGF binding sites under these conditions was $88 \pm 9.9$ (mean $\pm \mathrm{SE}$ ) fmol/mg protein. Each point represents the mean of three determinations. In all cases, the SE of the mean was less than $10 \%$ of the mean value. Similar results were obtained using hepatic membranes from fetal lambs at 79,123 , and 140 days of gestation and postnatal sheep at 3 days, 8 days, and 6 wk of age.

Thus the estimated concentration of EGF binding activity in the acid-ethanol extract, assuming no significant losses during chromatography, was $0.33 \mathrm{ng} / \mathrm{mg}$ protein.

To determine whether Bio-Gel fractions which displaced ${ }^{125} \mathrm{I}-$ 
mouse EGF from hepatic receptors also competed with ${ }^{125} \mathrm{I}$ mouse EGF for binding to specific antimouse EGF antibody, we examined the effect of receptor-active fractions in a homologous mouse EGF radioimmunoassay sensitive to $10-15 \mathrm{pg}$ of mouse EGF. As shown in Figure 4, the receptor-active Bio-Gel fractions had no detectable activity in the mouse EGF RIA.

The binding of ${ }^{125} \mathrm{I}$-EGF to livers of fetal sheep at varying stages of development was compared to the binding of EGF to livers of neonatal, postnatal nonpregnant, and pregnant sheep. As shown in Figure 5, specific ${ }^{125}$ I-EGF binding sites in fetal liver were detected as early as midgestation, and the number of EGF binding sites increased markedly in late gestation, reaching a peak of $80-100 \mathrm{fmol} / \mathrm{mg}$ protein at the time of birth. The number of EGF binding sites in fetal liver exceeded the number of EGF

Acid-ethanol Extract $(\square)$ or Bio-Gel Peaks $1(\bullet)$ and $2(\bullet)$, log $\mathrm{ng} /$ tube

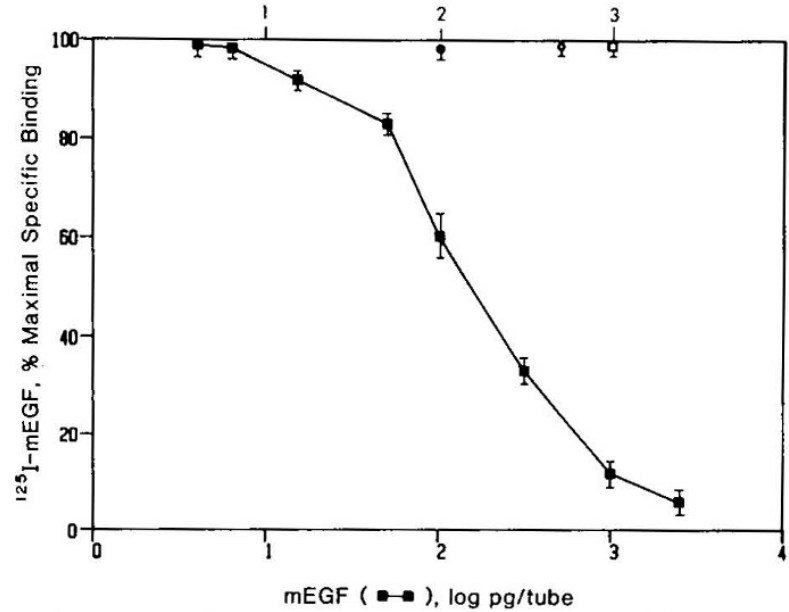

Fig. 4. The effects of an acid-ethanol extract of fetal kidney in a homologous mEGF RIA. ${ }^{125} \mathrm{I}-\mathrm{mEGF}(0.1 \mathrm{nM})$ was incubated with antimouse EGF antiserum in the absence or presence of increasing amounts


the pooled Bio-Gel peaks $1(O)$ and $2(\bullet)$ prepared as described in the legend to Figure 2. Each point represents the mean $\pm \mathrm{SE}$ of three determinations. Similar results were obtained in each of three experiments.

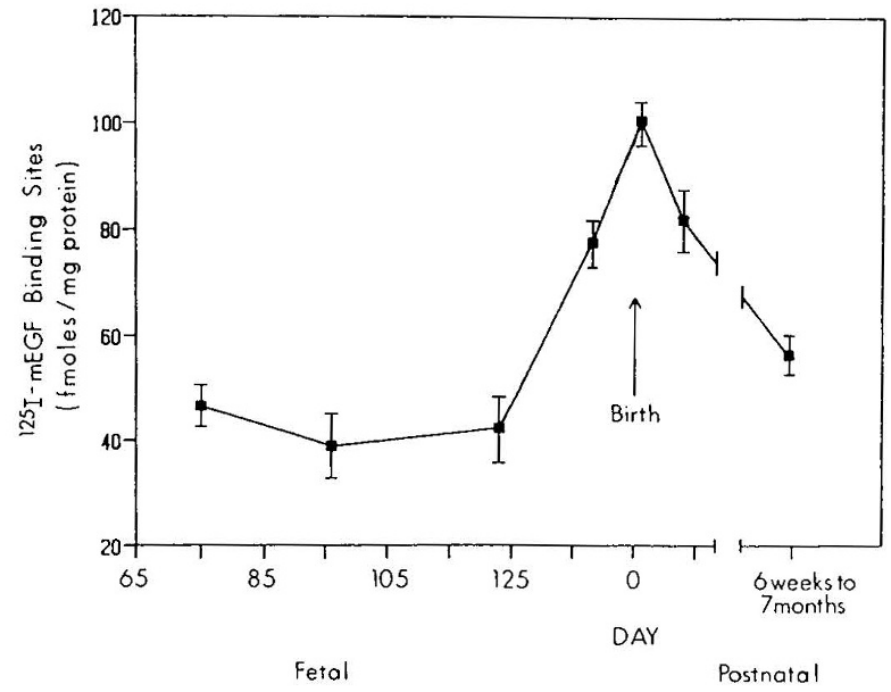

Fig. 5. Ontogeny of EGF binding sites in sheep liver. ${ }^{125} \mathrm{I}$-EGF $(0.5$ $\mathrm{nM}$ ) was incubated with $300 \mu \mathrm{g}$ membrane protein for $20 \mathrm{~h}$ at $4^{\circ} \mathrm{C}$. Each point represents the mean \pm SE of data obtained using hepatic microsomes from three or four sheep. Similar results were obtained in three separate experiments.



Fig. 6. EGF binding sites in fetal and pregnant sheep liver. ${ }^{125}$ I-EGF $(0.5 \mathrm{nM})$ was incubated with $500 \mu \mathrm{g}$ membrane protein for $20 \mathrm{~h}$ at $4^{\circ} \mathrm{C}$. Each point represents the mean \pm SE of data obtained using hepatic microsomes from three fetal and three pregnant sheep at 70-79 days of gestation (midgestation) and three fetal and three pregnant sheep at 130 141 days of gestation (late gestation). Similar results were obtained in three separate experiments.

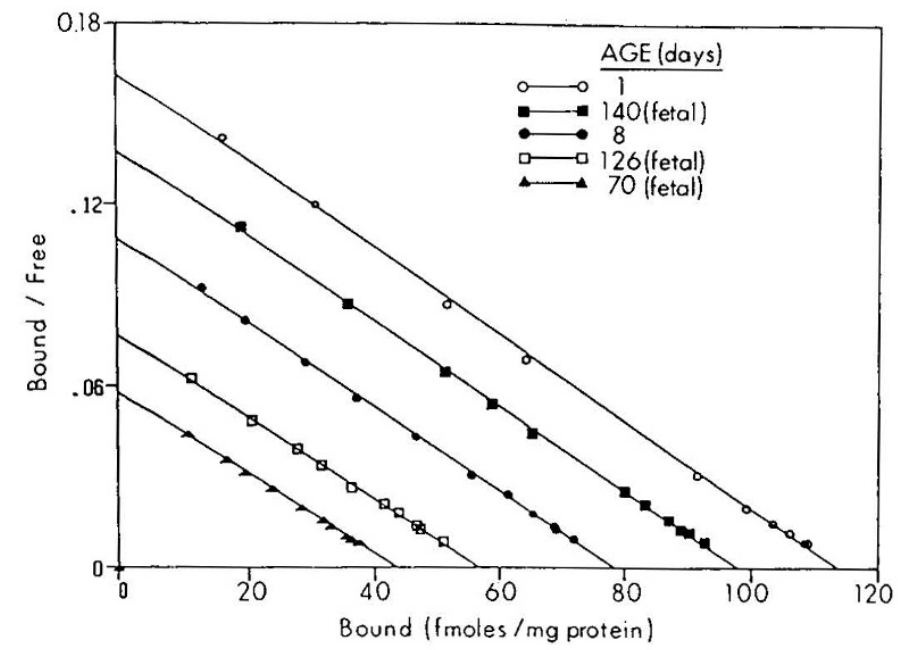

Fig. 7. Scatchard analysis of the binding of ${ }^{125}$ I-EGF to sheep liver membranes. ${ }^{125} \mathrm{I}$-EGF $(0.5 \mathrm{nM})$ was incubated with $300 \mu \mathrm{g}$ membrane protein for $20 \mathrm{~h}$ at $4^{\circ} \mathrm{C}$. Points represent the mean of three determinations

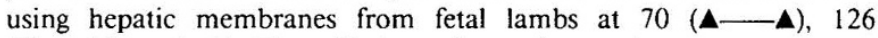
$(\square-\square)$, and $140(\square-\square)$ days of gestation, and postnatal nonpregnant sheep at $1\left(\mathrm{O}_{-}\right)$and 8 days of age $(-)$. In all cases the $\mathrm{SE}$ of the mean was less than $10 \%$ of the mean value.

binding sites in the livers of pregnant ewes, particularly in late gestation (Fig. 6). Scatchard plots of EGF binding curves (Fig. 7) at all stages of development were linear and were parallel to one another, indicating that there were no significant changes in the affinity of the EGF receptor during development.

\section{DISCUSSION}

The TGFs are a family of low molecular weight polypeptides which share the capacity to stimulate anchorage-independent growth of normal rat kidney fibroblasts in soft agar. TGF-like activity has been detected in extracts of whole mouse and rat embryos (14-17) and TGFs have been purified from conditioned media of murine sarcoma virus transformed cells and certain human tumor cells and from human placenta and human plate- 
lets (19). The results of the studies reported herein demonstrate the presence of TGF-like activity in the kidney of the ovine fetus. Acid-ethanol extracts of fetal kidney stimulated a dose-dependent increase in the number and size of colonies of NRK fibroblasts in soft agar. Like the TGFs identified in acid-ethanol extracts of conditioned media of transformed cells and of mouse embryos, the ovine fetal TGF is stable in $1 \mathrm{M}$ acetic acid and elutes as two peaks of colony-forming activity when chromatographed on BioGel. The apparent molecular weights of the two peaks of ovine fetal TGF activity (MW 14.5 and $9 \mathrm{~K}$ ) are comparable to the molecular weights of the TGFs detected in acid-ethanol extracts of mouse embryos (MW 20 and $10 \mathrm{~K})(16,34)$. However, the MW of the TGF-like activity in ovine fetal kidney cannot be determined precisely by gel-exclusion chromatography on BioGel. Some proteins, such as mouse EGF, adsorb to Bio-Gel and migrate anomalously on Bio-Gel columns. Thus, the apparent 14.5 and $9 \mathrm{~K}$ peaks of activity may not accurately represent the actual molecular mass of the TGF-like activity. In addition, it is possible that the 14.5 and $9 \mathrm{~K}$ peaks of activity may represent proteolytic fragments of a larger MW species. On the other hand, the two molecular weight forms of TGF activity in tissues of the ovine and mouse fetuses may represent a single TGF at different stages of cellular processing.

The two peaks of ovine fetal TGF-like activity detected in fractions eluting from Bio-Gel coincided with two peaks of EGF receptor-binding activity. Two lines of evidence suggest that the reduction in the binding of ${ }^{125} \mathrm{I}$-mouse EGF to EGF receptors caused by active Bio-Gel fractions did not result from degradation of the EGF tracer or protelysis of the EGF receptor: 1) the specific binding of radiolabeled EGF which had previously been incubated with active Bio-Gel fractions was comparable to the specific binding of EGF tracer incubated with assay buffer alone; and 2) the specific binding of ${ }^{125} \mathrm{I}-\mathrm{EGF}$ to hepatic microsomes preincubated with active Bio-Gel fractions was comparable to the specific binding of ${ }^{125} \mathrm{I}-\mathrm{EGF}$ to hepatic microsomes preincubated in receptor assay buffer alone. Thus, the ability of Bio-Gel column fractions to compete with ${ }^{125}$ I-EGF for binding to sheep hepatic receptors resulted from the binding of ovine fetal EGFlike TGF(s) to EGF receptors. The failure of receptor-active fractions to compete with ${ }^{125} \mathrm{I}$-mouse EGF for binding to specific antimouse EGF antibody is consistent with previous studies demonstrating that TGFs do not cross-react with mouse EGF in a $\operatorname{RIA}(18,19,35)$.

The members of the $\mathrm{TGF}_{\text {; }}$ family have been classified as type $\alpha$ or type $\beta$ TGFs on the basis of the differential binding of the peptides to EGF receptors and the differential effects of the peptides on colony formation of NRK fibroblasts in soft agar (35). TGF- $\alpha$ competes with EGF for binding to EGF receptors and stimulates the formation of small colonies $\left(850-3100 \mu \mathrm{M}^{2}\right)$ of NRK fibroblasts in soft agar. TGF- $\beta$, on the other hand, does not bind to EGF receptors but induces the formation of large colonies $\left(>3100 \mu \mathrm{M}^{2}\right)$ of NRK cells in soft agar if cultured in the presence of TGF- $\alpha$ or EGF. TGF- $\beta$ alone has no transforming activity for NRK cells in the soft agar assay. The demonstration that acid-ethanol extracts of ovine fetal kidney bind to EGF receptors and stimulate the formation of large colonies of NRK cells in soft agar suggests the presence of TGF- $\alpha$ as well as TGF$\beta$-like activity in the ovine fetus.

When acid-ethanol extracts of ovine fetal kidney were chromatographed on Bio-Gel, neither TGF-like colony-forming activity nor EGF receptor-binding activity were detected in fractions coeluting with ${ }^{125} \mathrm{I}$-mouse: EGF. This observation suggests that ovine TGF may predominate in the ovine fetus and may play an EGF-like role in avine fetal development. This hypothesis is consistent with previous studies demonstrating that the concentration of TGF $\alpha$ in whole extracts of mouse embryos greatly exceeds that of mouse EGF (34). We cannot, however, exclude the possibility that ovine EGF elutes from Bio-Gel in a manner which differs from that of mouse EGF. Moreover, the relative concentrations of TGF and EGF in ovine fetal tissues may vary at different stages of development.
Specific, high affinity EGF binding sites were detected in the livers of fetal, postnatal nonpregnant, and pregnant sheep. EGF binding sites in fetal liver were demonstrable as early as midgestation. Because both EGF and TGF- $\alpha$ bind with high affinity to EGF receptors $(18,19,35)$, these EGF binding sites in ovine fetal liver may represent receptors for EGF and/or TGF- $\alpha$. The number of fetal EGF receptors per mg protein increased during the latter part of gestation, exceeding the number of EGF binding sites in the liver of the pregnant ewe and reaching a peak at the time of birth. Studies by Adamson and Meek (3) in the fetal mouse demonstrated a similar marked increase in the number of hepatic EGF receptors during the latter third of gestation. The cause for the late-gestational increase in fetal EGF binding sites is unclear. Studies in postnatal rats indicate that the number of hepatic EGF receptors is dependent on thyroid status (36). Since the plasma concentrations of total and free thyroxine in the ovine fetus increase dramatically from day 60 until term and exceed the concentrations of total and free thyroxine in the pregnant ewe (37), the number of EGF receptors in ovine fetal liver may be regulated in part by thyroid hormone.

Our studies provide evidence for the existence of EGF-like TGF activity in the sheep fetus. The presence of EGF-like TGF activity in ovine fetal kidney and high affinity EGF receptors in ovine fetal liver strongly implicate a role for TGF in the growth and development of the ovine fetus.

Acknowledgments. The authors thank Dr. Stuart Handwerger for critical review of the manuscript and Gayle Kerr for secretarial assistance.

\section{REFERENCES}

1. Carpenter G, Cohen S 1979 Epidermal growth factor. Ann Rev Biochem 48:193-216

2. Adamson ED, Deller MJ, Warshaw JB 1981 Functional EGF receptors are present on mouse embryo tissues. Nature 291:656-659

3. Adamson ED, Meek J 1984 The ontogeny of epidermal growth factor receptors during mouse development. Dev Biol 103:62-70

4. Freemark M 1986 Epidermal growth factor stimulates glycogen synthesis in fetal rat hepatocytes: comparison with the glycogenic effects of IGF-I and insulin. Endocrinology 119:522-526

5. Richman RA, Benedict MR, Florini JR, Toly BA 1985 Hormonal regulation of somatomedin secretion by fetal rat hepatocytes in primary culture. Endocrinology 116:180-188

6. Atkison PR, Bala RM, Hollenberg MD 1984 Somatomedin-like activity from cultured embryo-derived cells: partial characterization and stimulation of production by epidermal growth factor (urogastrone). Can J Biochem Cell Biol 62:1335-1342

7. Hill DJ, Holder AT, Seid J, Preece MA, Tomlinson S, Milner RDG 1983 Increased thymidine incorporation into fetal rat cartilage in vitro in the presence of human somatomedin, epidermal growth factor and other growth factors. J Endocrinol 96:489-497

8. Crickard K, Ill CR, Jaffe RB 1981 Control of proliferation of human fetal adrenal cells in vitro. J Clin Endocrinol Metab 53:790-796

9. Gross I, Dynia DW, Rooney SA, Smart DA, Warshaw JB, Sissom JF, Hoath SB 1986 Influence of epidermal growth factor on fetal rat lung development in vitro. Pediatr Res 20:473-477

10. Perheentupa J, Lakshmanan J, Fisher DA 1985 Urine and kidney epidermal growth factor: ontogeny and sex difference in the mouse. Pediatr Res 19:428432

11. Walker P, Weichsel ME Jr, Eveleth D, Fisher DA 1982 Ontogenesis of nerve growth factor and epidermal growth factor in submaxillary glands and nerve growth factor in brains on immature male mice: correlation with ontogenesis of serum levels of thyroid hormones. Pediatr Res 16:520-524

12. Callegari C, Laborde NP, Lakshmanan J, Alm J, George-Nascimento C, Leake RD, Fisher DA 1985 A highly sensitive RIA system for human epidermal growth factor (EGF). Pediatr Res 19:618(abstr 91)

13. Mattila A-L, Perheentupa J, Pesonen K, Viinika L 1985 Epidermal growth factor in newborn urine from birth to puberty. J Clin Endocrinol Metab 61:997-1000

14. Nexo E, Hollenberg MD, Figueroa A, Pratt RM 1980 Detection of epidermal growth factor-urogastrone and its receptor during fetal mouse development. Proc Natl Acad Sci USA 77:2782-2785

15. Proper JA, Bjornson CL, Moses HL 1982 Mouse embryos contain polypeptide growth factor(s) capable of inducing a reversible neoplastic phenotype in nontransformed cells in culture. J Cell Physiol 110:169-174

16. Twardzik DR, Ranchalis JE, Todaro GJ 1982 Mouse embryonic transforming growth factors related to those isolated from tumor cells. Cancer Res 42:590593

17. Matrisian LM, Pathak M, Magun BE 1982 Identification of an epidermal growth factor-related transforming growth factor from rat fetuses. Biochem Biophys Res Commun 107:761-769 
18. Todaro GJ, Fryling C. DeLarco JE 1980 Transforming growth factors produced by certain human tumor cells: Polypeptides that interact with epidermal growth factor receptors. Proc Natl Acad Sci USA 77:5258-5262

19. Roberts AB. Frolik CA. Anzano MA. Sporn MB 1983 Transforming growth factors from neoplastic and nonneoplastic tissues. Fed Proc 42:2621-2626

20. Smith JM, Sporn MB, Roberts AB, Derynck R, Winkler ME. Gregory H 1985 Human transforming growth factor- $\alpha$ causes precocious eyelid opening in newborn mice. Nature 315:515-516

21. Ibbotson KJ, Twardzik DR, D'Souza SM, Hargreaves WR, Todaro GJ. Mundy GR 1985 Stimulation of bone resorption in vitro by synthetic transforming growth factor-alpha. Science 228:1007-1009

22. Ibbotson KJ, Harrod J, Gowen M, D'Souze S, Smith DD. Winkler ME, Derynck R, Mundy GR 1986 Human recombinant transforming growth factor $\alpha$ stimulates bone resorption and inhibits formation in vitro. Proc Natl Acad Sci USA 83:2228-2232

23. Rhodes JA. Tam JP. Finke U, Saunders M, Bernanke J, Silen W, Murphy RA 1986 Transforming growth factor $\alpha$ inhibits secretion of gastric acid. Proc Natl Acad Sci USA 83:3844-3846

24. Schreiber AB, Einkley ME, Derynck R 1986 Transforming growth factor- $\alpha$ : more potent angiogenic mediator than epidermal growth factor. Science 232:1250-1253

25. Sundell HW, Gray ME, Serenius FS, Escobedo MG, Stahlman MT 1980 Effects of epidermal growth factor on lung maturation in fetal lambs. Am J Pathol 100:707-726

26. Thorburn GD, Waters MJ, Young IR, Dolling M, Buntine D, Hopkins PS 1981 Epidermal growth factor: a critical factor in fetal maturation? In: The Fetus and Independent Life. Ciba Foundation Symposium 86, Pitman. London, pp 172-198
27. Hurley TW. D'Ercole AJ. Handwerger S. Underwood LE, Furlanetto RW Fellows RE 1977 Isolation and structural characterization of ovine placental lactogen. Biochemistry 16:5598-5604

28. Roberts AB, Lamb LC. Newton DL, Sporn MB, DeLarco JE, Todaro GJ 1980 Transforming growth factors: isolation of polypeptides from virally and chemically transformed cells by acid/ethanol extraction. Proc Natl Acad Sci USA 77:3494-3498

29. Tsushima T, Friesen HG 1973 Radioreceptor assay for growth hormone. J Clin Endocrinol Metab 37:334-337

30. Bradford MM $1976 \mathrm{~A}$ rapid and sensitive method for the quantification of microgram quantities of protein utilizing the principle of protein-dye binding. Anal Biochem 72:248-254

31. Dixon TF. Purdom M 1954 Serum 5'nucleotidasc. J Clin Pathol 7:341-343

32. Scatchard G 1949 The attraction of proteins for small molecules and ions Ann NY Acad Sci 51:660-672

33. Hoath SB, Lakshmanan J. Scott SM. Fisher DA 1983 Effect of thyroid hormones on epidermal growth factor concentration in neonatal mouse skin. Endocrinology 112:308-314

34. Twardzik DR 1985 Differential expression of transforming growth factor- $\alpha$ during prenatal development of the mouse. Cancer Res 45:5413-5416

35. Anzano MA, Roberts AB, Smith JM. Sporn MB, DeLarco JE 1983 Sarcoma growth factor from conditioned medium of virally transformed cells is composed of both type $\alpha$ and type $\beta$ transforming growth factors. Proc Natl Acad Sci USA 80:6264-6268

36. Mukku VR 1984 Regulation of epidermal growth factor receptor levels by thyroid hormone. J Biol Chem 259:6543-6547

37. Nathanielsz PW 1976 The fetal thyroid. In: Fetal Endocrinology: An Experimental Approach. North-Holland, Amsterdam, pp 53-72 